\title{
Periglacial landscape dynamics in the western Canadian Arctic: Results from a thermokarst lake record on a push moraine (Herschel Island, Yukon Territory)
}

\author{
Josefine Lenz $^{\text {a,* }}$, Michael Fritz a, Lutz Schirrmeister ${ }^{a}$, Hugues Lantuit ${ }^{a}$, Matthew J. Wooller ${ }^{\text {b,c }}$, \\ Wayne H. Pollard ${ }^{\mathrm{d}}$, Sebastian Wetterich ${ }^{\text {a }}$ \\ a Alfred Wegener Institute for Polar and Marine Research, Department of Periglacial Research, Telegrafenberg A43, 14473 Potsdam, Germany \\ b University of Alaska Fairbanks, Water E' Environmental Research Center and School of Fisheries E' Ocean Sciences, Fairbanks, AK 99775, USA \\ c University of Alaska Fairbanks, Alaska Quaternary Center, Fairbanks, AK 99775, USA \\ d McGill University, Department of Geography, 805 Sherbrooke St. West, H3A2K6 Montreal, Quebec, Canada
}

\section{A R T I C L E I N F O}

\section{Article history:}

Received 13 April 2012

Received in revised form 4 April 2013

Accepted 7 April 2013

Available online 20 April 2013

\section{Keywords:}

Paleolimnology

Holocene thermal maximum

Thermokarst

Permafrost

Canadian Arctic

Herschel Island

\begin{abstract}
A B S T R A C T
Ice-rich permafrost landscapes are sensitive to climate and environmental change due to the melt-out of ground ice during thermokarst development. Thermokarst processes in the northern Yukon Territory are currently not well-documented. Lake sediments from Herschel Island $\left(69^{\circ} 36^{\prime} \mathrm{N} ; 139^{\circ} 04^{\prime} \mathrm{W}\right)$ in the western Canadian Arctic provide a record of thermokarst lake development since the early Holocene. A $727 \mathrm{~cm}$ long lake sediment core was analyzed for radiographic images, magnetic susceptibility, granulometry, and biogeochemical parameters (organic carbon, nitrogen, and stable carbon isotopes). Based on eight calibrated AMS radiocarbon dates, the sediment record covers the last $\sim 11,500$ years and was divided into four lithostratigraphic units (A to D) reflecting different thermokarst stages. Thermokarst initiation at the study area began $\sim 11.5 \mathrm{cal} \mathrm{ka}$ BP. From $\sim 11.5$ to $10.0 \mathrm{cal} \mathrm{ka}$ BP, lake sediments of unit A started to accumulate in an initial lake basin created by melt-out of massive ground ice and thaw subsidence. Between 10.0 and 7.0 cal ka BP (unit B) the lake basin expanded in size and depth, attributed to talik formation during the Holocene thermal maximum. Higher-than-modern summer air temperatures led to increased lake productivity and widespread terrain disturbances in the lake's catchment. Thermokarst lake development between 7.0 and 1.8 cal ka BP (unit C) was characterized by a dynamic equilibrium, where lake basin and talik steadily expanded into ambient ice-rich terrain through shoreline erosion. Once lakes become deeper than the maximum winter lake ice thickness, thermokarst lake sediments show a great preservation potential. However, site-specific geomorphic factors such as episodic bank-shore erosion or sudden drainage through thermo-erosional valleys or coastal erosion breaching lake basins can disrupt continuous deposition. A hiatus in the record from 1.8 to $0.9 \mathrm{cal} \mathrm{ka} \mathrm{BP}$ in Lake Herschel likely resulted from lake drainage or allochthonous slumping due to collapsing shore lines before continuous sedimentation of unit D recommenced during the last 900 years.
\end{abstract}

(c) 2013 Elsevier B.V. All rights reserved.

\section{Introduction}

Beginning with the Pleistocene-Holocene transition, the waning of the Laurentide Ice Sheet (LIS) led to a complete reorganization of landscapes that were formerly ice-covered or situated in proximity to the ice margin (Kaufman and Manley, 2004). Ice-rich permafrost landscapes like moraine belts quickly changed their morphology, hydrology, and depositional dynamics due to thermokarst processes related to the melt-out of ground ice and thaw settlement (e.g. Czudek and Demek, 1970; Rampton, 1974, 1982, 1988; Murton et al., 1998). Periglacial landscapes are sensitive to climate and environmental changes (e.g. Burn and Zhang, 2009) and these changes can be recorded in thermokarst lake sediments (Murton, 1996). So far, there exist only a few

\footnotetext{
* Corresponding author. Tel.: + 49331288 2204; fax: +49 3312882137

E-mail address: Josefine.Lenz@awi.de (J. Lenz).
}

palaeoenvironmental datasets from push moraines in the western Canadian Arctic that aim at reconstructing the variety of environmental responses from a periglacial perspective taking into account thermokarst onset, lake basin development, and limnogeological succession (Rampton, 1988; Spear, 1993; Murton, 1996, 2001).

Rapidly ameliorating temperatures during the Bølling/Allerød interstadial ( 14.7 to 13 cal ka BP) are documented in the northern Yukon, inferred from pollen spectra and chironomid assemblages (Viau et al., 2008; Kurek et al., 2009; Fritz et al., 2012a; Irvine et al., 2012). However, regional lake development was probably still suppressed due to sustained dry conditions caused by continentality effects (Burn, 1997) of a lower glacio-eustatic sea level (Hill et al., 1985; Keigwin et al., 2006) and an almost permanent sea-ice cover (Bradley and England, 2008; Scott et al., 2009). Between 13 and 8 cal ka BP thermokarst activity occurred widely on the arctic coastal plains of Canada (Rampton, 1974, 1982, 1988) and Alaska (Williams and Yeend, 1979; Carter, 
1988; Hopkins and Kidd, 1988) and on the plains of northeast Siberia (Tomirdiaro, 1982; Romanovskii et al., 2000) during the Holocene thermal maximum (HTM, Kaufman et al., 2004). Thermokarst activity was extremely intense at 10-9 cal ka BP, causing widespread terrain disturbance, regional active layer deepening (Mackay, 1978; Burn, 1997; Murton et al., 1997), numerous retrogressive thaw slumps, and the development of thermokarst basins in ice-rich terrain (Rampton, 1974). Ponds formed at locations with high relief, incomplete deglaciation, or postglacial ground ice aggradation, and developed into thermokarst lakes as the basins expanded. As climate warming ceased during the middle Holocene (e.g. Ritchie, 1984), thermokarst activity diminished (Rampton, 1974). Today, thermokarst lakes in continuous permafrost regions are actively and rather constantly expanding as a result of surface permafrost degradation (Smith et al., 2005; Jones et al., 2011). In coastal areas, thermal degradation of permafrost occurs locally and episodically, for example in areas of coastal erosion (Lantuit et al., 2012). Records documenting postglacial landscape evolution and palaeoenvironmental change at the northwestern LIS margin in a coastal setting are rare and often focus on vegetation changes (e.g. Ritchie and Hare, 1971; Ritchie et al., 1983; Spear, 1993; Vardy et al., 1997). Thermokarst lakes and their sedimentary records often go unrecognized (Hopkins and Kidd, 1988; Murton, 1996) though they have a high preservation potential (Murton, 2001).

Here, we present a multi-proxy palaeoenvironmental reconstruction using sediments from a thermokarst lake located on a push moraine that makes up Herschel Island. This study highlights the limnogeological succession of a thermokarst lake in an ice-rich arctic periglacial environment since the beginning of the Holocene. Our dataset represents the northernmost postglacial paleoenvironmental archive of the Yukon Territory and one of the northernmost in the western Canadian Arctic, where multi-proxy analyses on lacustrine sequences are rare. We put this dataset into context with existing regional records covering the last glacial-interglacial transition and the Holocene to assess the palaeoenvironmental significance of thermokarst lake sediment records for portraying regional climate evolution and to distinguish this from effects of local permafrost conditions leaving their imprint in the sedimentary record.

\section{Study area}

The Coastal Plain of the Yukon Territory in Canada (Fig. 1) extends north-south over approximately $24 \mathrm{~km}$ and spans $200 \mathrm{~km}$ from west to east, from the Alaska-Yukon border to the Mackenzie River delta (Bouchard, 1974). Signs of glacigenic deformation and glacial deposits, such as morainic ridges and erratic boulders, attest to the presence of a major glacial advance in the area extending from Shingle Point westward beyond Herschel Island (Rampton, 1982). Herschel Island $\left(69^{\circ} 36^{\prime} \mathrm{N} ; 139^{\circ} 04^{\prime} \mathrm{W}\right)$, the northernmost part of the Yukon Territory, is located $250 \mathrm{~km}$ northwest of Inuvik (Northwest Territories), $60 \mathrm{~km}$ east of the Alaska-Yukon border, and $3 \mathrm{~km}$ off the mainland coast (Fig. 1). This rhombic-shaped island has an area of $108 \mathrm{~km}^{2}$ and a maximum elevation of $183 \mathrm{~m}$ above sea level ( $\mathrm{m}$ a.s.l.) (de Krom, 1990).

The push moraine of Herschel Island ridge is of Pleistocene origin and was formed by LIS glacier ice-thrusting of material from the subaerially exposed continental shelf that later became Herschel Island and the offshore Herschel Basin after Holocene sea level rise (Mackay, 1959; Burn, 2009). The island is primarily composed of upthrust beds of shell-bearing and salty marine sands, silts, and silty clays containing different forms of ground ice. Ground ice on Herschel Island constitutes up to $70 \%$ of the upper 10 to $15 \mathrm{~m}$ of permafrost and occurs as segregated ice lenses, ice wedges, pore ice, and massive tabular ice bodies in the form of buried glacier ice, snow bank ice, and massive segregated ice (Pollard, 1990). Ice-wedge polygons have

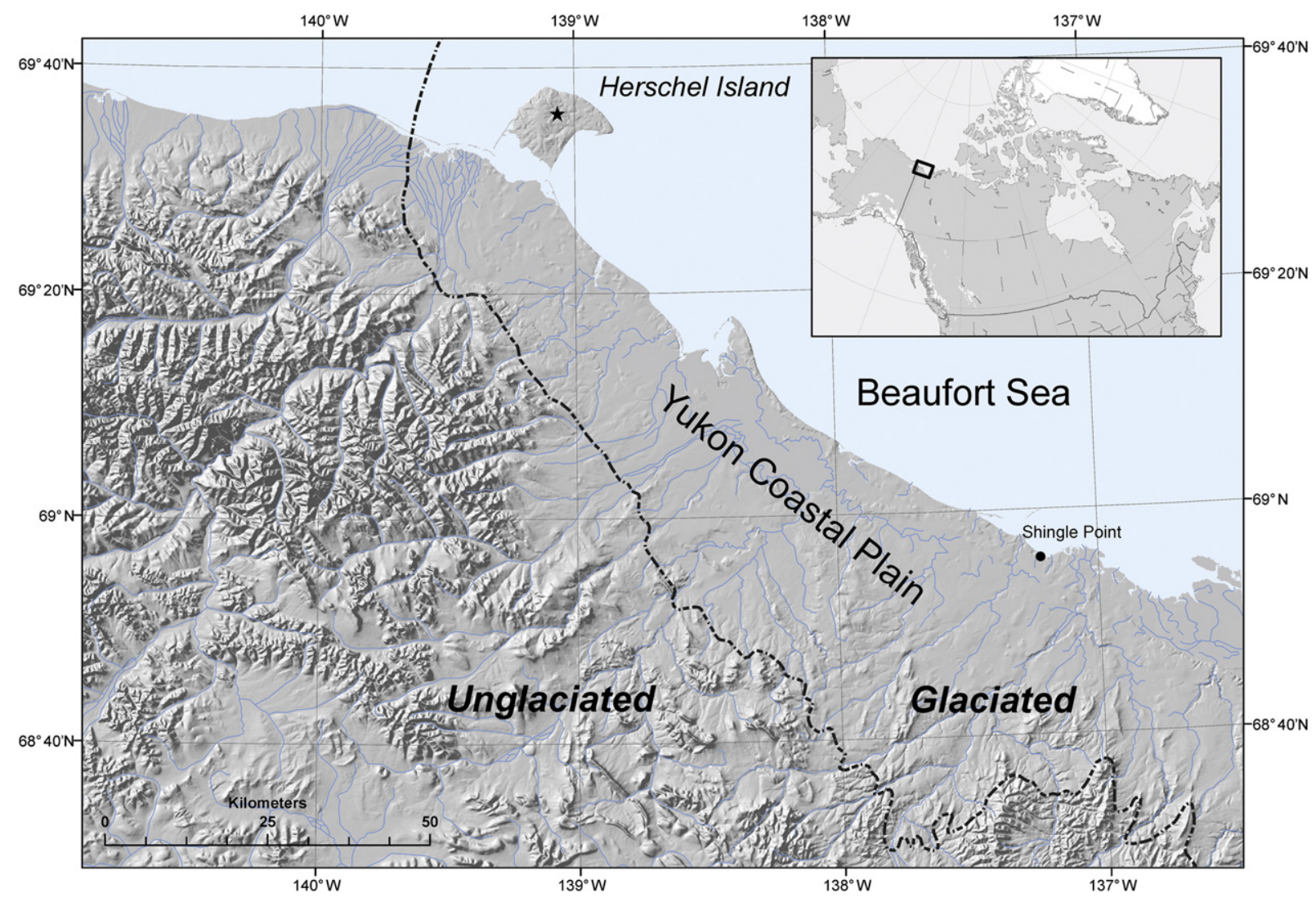

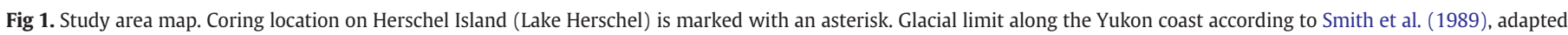
from Rampton (1982) and Dyke and Prest (1987). 
formed since deglaciation in flat areas of the island; some have evolved into thermokarst ponds.

Lake Herschel (informal name) is about $0.126 \mathrm{~km}^{2}$ in area and is located in the center of Herschel Island at an elevation of about $75 \mathrm{~m}$ a.s.l. (Fig. 2). The lake is subcircular and $400 \mathrm{~m}$ in diameter, with a maximum water depth of about $6 \mathrm{~m}$ (Fig. 2). The main part of the relatively small catchment area $\left(\sim 0.5 \mathrm{~km}^{2}\right)$ is situated west of the lake where the hinterland elevation is as high as $100 \mathrm{~m}$ a.s.l. and where influent water is supplied. Groundwater flow to the lake is controlled by a shallow permafrost table; an active-layer depth of about $25 \mathrm{~cm}$ was measured adjacent to the lake. Spatial variations in active layer thickness and near-surface ground ice conditions are described in detail by Burn and Zhang (2009). Lake water temperatures ranged from about $8{ }^{\circ} \mathrm{C}$ in summers 2006, 2008, 2009, and 2010 to about $1{ }^{\circ} \mathrm{C}$ below the ice cover in spring 2009 (Table 1). Uniform values of temperature, electrical conductivity (EC) and $\mathrm{pH}$ measured in summer 2008 at depths of 150,350 , and $500 \mathrm{~cm}$ indicate a mixed water body in summer and confirm a cold-monomictic lake circulation. The relatively high modern lake water EC of about $1000 \mu \mathrm{S} / \mathrm{cm}$ is typical for an athalassic brackish environment. The major lake water ion source is likely the salty upthrust marine sediments (Kokelj et al., 2002; Fritz et al., 2012b). The increased EC in winter is explained by a $\sim 2$ m thick ice cover (April 2009) that concentrates ions in the liquid phase.

\section{Material and methods}

The bathymetry of Lake Herschel was measured with echo sounding through drill holes in the lake ice in 2009. Pre-site surveys in 2008 yielded global positioning data (Garmin GPS 12) from the shoreline and echo-sounding data (hand-held depth sounder) from the lake basin as well as water samples from different depths. Surface water samples were taken during the summers of 2006, 2008, 2009, and 2010. EC and $\mathrm{pH}$ values were determined using a pH-conductivity meter (MultiLab 540, WTW).
Table 1

Hydrochemical characteristics of water samples taken from Lake Herschel at different depths and from different seasons.

\begin{tabular}{lclll}
\hline Date of sampling & $\begin{array}{l}\text { Water depth } \\
(\mathrm{cm})\end{array}$ & $\mathrm{pH}$ & $\begin{array}{l}\mathrm{EC} \\
(\mu \mathrm{S} / \mathrm{cm})\end{array}$ & $\begin{array}{l}\mathrm{T} \\
\left({ }^{\circ} \mathrm{C}\right)\end{array}$ \\
\hline August 2008 & 0 & - & 1095 & - \\
April 2009 & 0 & 7.50 & 2303 & 1.2 \\
July 2010 & 0 & 7.22 & 1119 & - \\
July 2006 & 40 & 8.31 & 1096 & 8.3 \\
August 2008 & 150 & 8.34 & 1095 & 8.5 \\
August 2008 & 350 & 8.27 & 1093 & 8.4 \\
August 2008 & 500 & 8.32 & 1098 & 8.4 \\
\hline
\end{tabular}

A $727 \mathrm{~cm}$ long sediment core (core code: PG1967) was retrieved from Lake Herschel in April 2009 with a piston corer (UWITEC) in a water depth of $527 \mathrm{~cm}$. The piston corer was operated with a tripod on the $\sim 2 \mathrm{~m}$ thick lake ice. The PVC liner filled with sediments was cut into pieces of up to $100 \mathrm{~cm}$ and stored cold, but unfrozen, until laboratory analysis. The working half was used for destructive analyses (e.g. granulometry and biogeochemical analyses), whereas nondestructive analyses (e.g. radiographic images and mass-specific magnetic susceptibility [MS]) were conducted using the archive half of the core.

Radiography profiles based on X-ray were used to display density differences and to describe bedding, bioturbation, and deformation structures. The ITRAX core scanner at the University of Cologne (Germany) operates at $55 \mathrm{kV}$ and $50 \mathrm{~mA}$ and creates 2D positive radiographic images with a resolution of $200 \mu \mathrm{m}$ without automatic gray level adjustments as well as high-definition photographs with an optical camera system (Croudace et al., 2006).

The mass-specific MS was measured with a Multi-Sensor Core Logger (GEOTEK, MSCL) and is expressed in SI units $\left(10^{-5} \mathrm{~m}^{3} \mathrm{~kg}^{-1}\right)$. The water content was calculated using the weight difference between fresh and freeze-dried bulk sediment samples and is expressed as weight percentage (wt.\%). The grain size distribution was measured

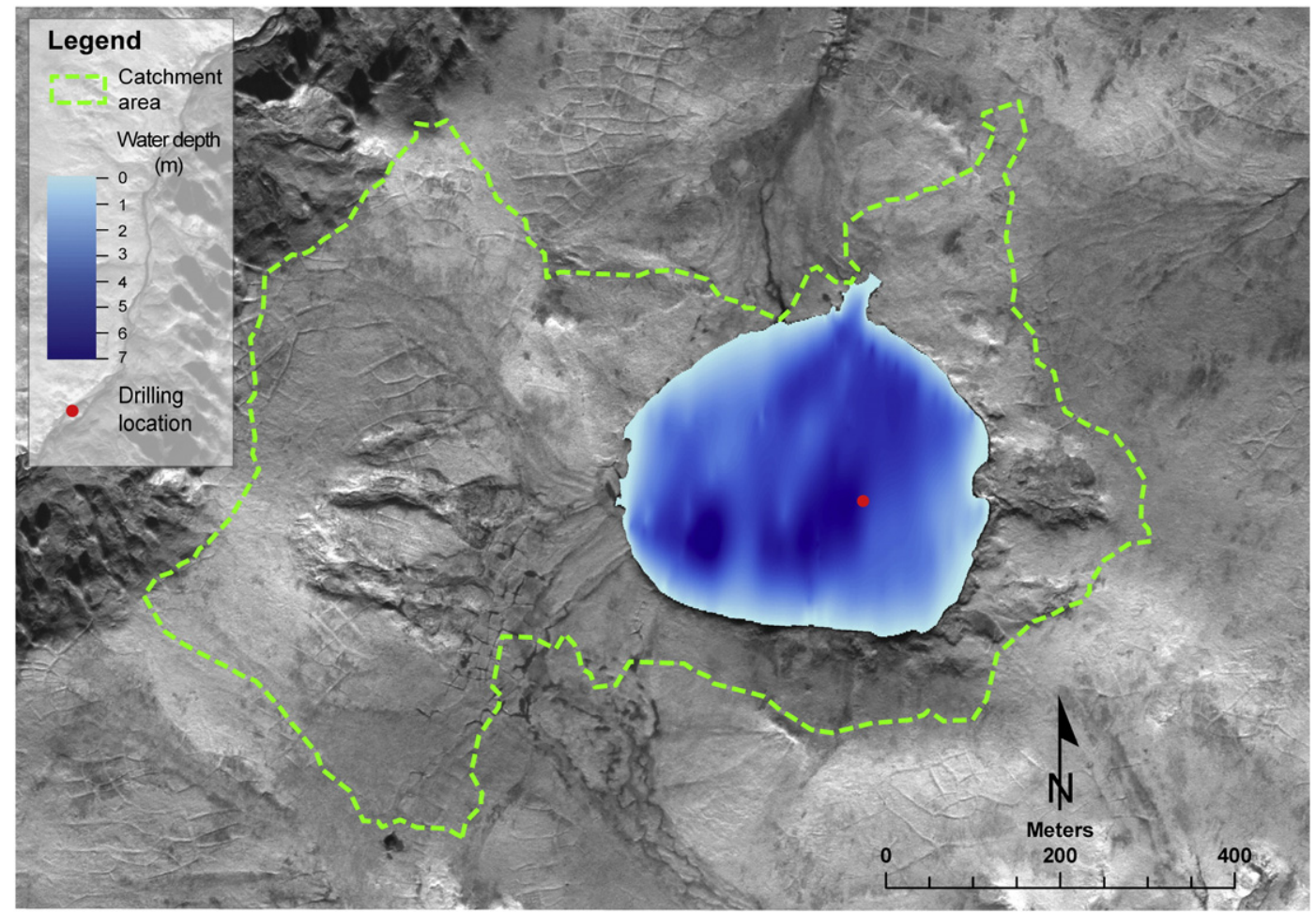

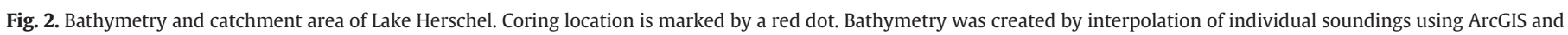
displayed in an IKONOS (2000) satellite image. 
(according to EN ISO 14688) using a laser particle size analyser (Coulter LS 200) from which the organic matter had been previously removed with hydrogen peroxide $\left(\mathrm{H}_{2} \mathrm{O}_{2}, 30 \%\right)$.

Total nitrogen (TN), total carbon (TC), and total organic carbon (TOC) were measured with an elemental analyzer (Elementar Vario EL III, with an analytical accuracy of $\pm 0.1 \mathrm{wt} . \%)$. The total inorganic carbon (TIC) content was calculated using the TC and TOC data (TIC $=$ TC - TOC). The calcium carbonate content was calculated from the TIC using the molar mass ratio of calcium carbonate and carbon $\left(\mathrm{CaCO}_{3}=8.33 \cdot \mathrm{TIC}\right)$. The $\mathrm{C} / \mathrm{N}$-ratio $(\mathrm{TOC} / \mathrm{TN})$ was calculated as an indicator for organic matter origin and $\delta^{13} \mathrm{C}$ values of TOC were measured using an elemental analyzer (Carlo-Erba CN2500) attached to a stable isotope ratio mass spectrometer (DELTAplusXL, Finnigan) at the German Research Centre of Geosciences (GFZ) in Potsdam, Germany. $\delta^{13} \mathrm{C}_{\mathrm{TOC}}$ values are expressed relative to the Vienna Pee Dee Belemnite (VPDB) standard in per mill (\%) and the analytical precision was $\leq \pm 0.02 \%$ ( $1 \sigma)$.

Accelerator Mass Spectrometry (AMS) radiocarbon age determination of macroscopic plant remains and mollusk shells was carried out on wet-sieved and hand-picked samples (>250 $\mu \mathrm{m})$. Nine samples of plant detritus including moss, leaves, and wood remains, and one sample of two connected mollusk valves (Pisidium sp.) were dated at the Poznan Radiocarbon Laboratory (Poland). The AMS dates were calibrated using CALIB 6.0 and INTCAL09 (Reimer et al., 2009). All geochronological dates in this study are reported in calibrated years before $1950 \mathrm{AD}$, referred as before present (cal ka BP).

\section{Results}

\subsection{Core lithology}

The sediment from Lake Herschel core PG1967 is characterized by gray, consolidated, fine-grained deposits with irregularly interbedded strata. Based on lithological descriptions, radiographic images, photographs, and the analyzed sedimentary parameters, the core is divided into four lithostratigraphic units:

- Unit A: $727-700 \mathrm{~cm}$

- Unit B: 700-600 cm

- Unit C: 600-200 cm

- Unit D: 200-0 cm.

The boundaries at $700 \mathrm{~cm}$ (between units A and B) and $200 \mathrm{~cm}$ (between units $C$ and $D$ ) are evident from changes in sediment texture and structure, and are confirmed by variations in grain size parameters, density, water content, MS, and biogeochemical parameters, whereas the boundary at $600 \mathrm{~cm}$ (between units B and C) is primarily based on changes of biogeochemical parameters.

Unit A is composed of light-gray, compact, fine-grained clayey sediment that does not contain any visible biogenic fossil matter. The material is compact and weakly bedded (Fig. 3). The transition to unit $B$ is marked by minerogenic material with embedded wood remains at 697, 703, and $705 \mathrm{~cm}$ depth. Alternations of organic-rich dark-gray and minerogenic light-gray beds occur in unit B every 6 to $17 \mathrm{~cm}$. A peaty layer at 683 to $684 \mathrm{~cm}$ depth was sampled for radiocarbon dating. Plant and mollusk remains are present at 646 to $647 \mathrm{~cm}$ core depth. Unit C sediment is gray and is less moist and less consolidated than unit B sediment, with frequent recurring layers. Mollusk remains are present at 572 to $574 \mathrm{~cm}$, wood remains at $498 \mathrm{~cm}$, and plant fragments at 528 and 366 to $367 \mathrm{~cm}$. Material extrusion upon core recovery due to degassing of methane after decompression likely caused gaps of 2 to $15 \mathrm{~cm}$ between 515 and $610 \mathrm{~cm}$ core depth. Small-scale crevices $(<1 \mathrm{~mm})$ with brown discoloration due to iron oxidation are located at organic-rich layers between 468 and $527 \mathrm{~cm}$. A distinct light-gray sandy bed of coarser grain size from 197 to $204 \mathrm{~cm}$ is followed by an organic-rich and more fine-grained dark-gray layer at 194 to $197 \mathrm{~cm}$. This marks the

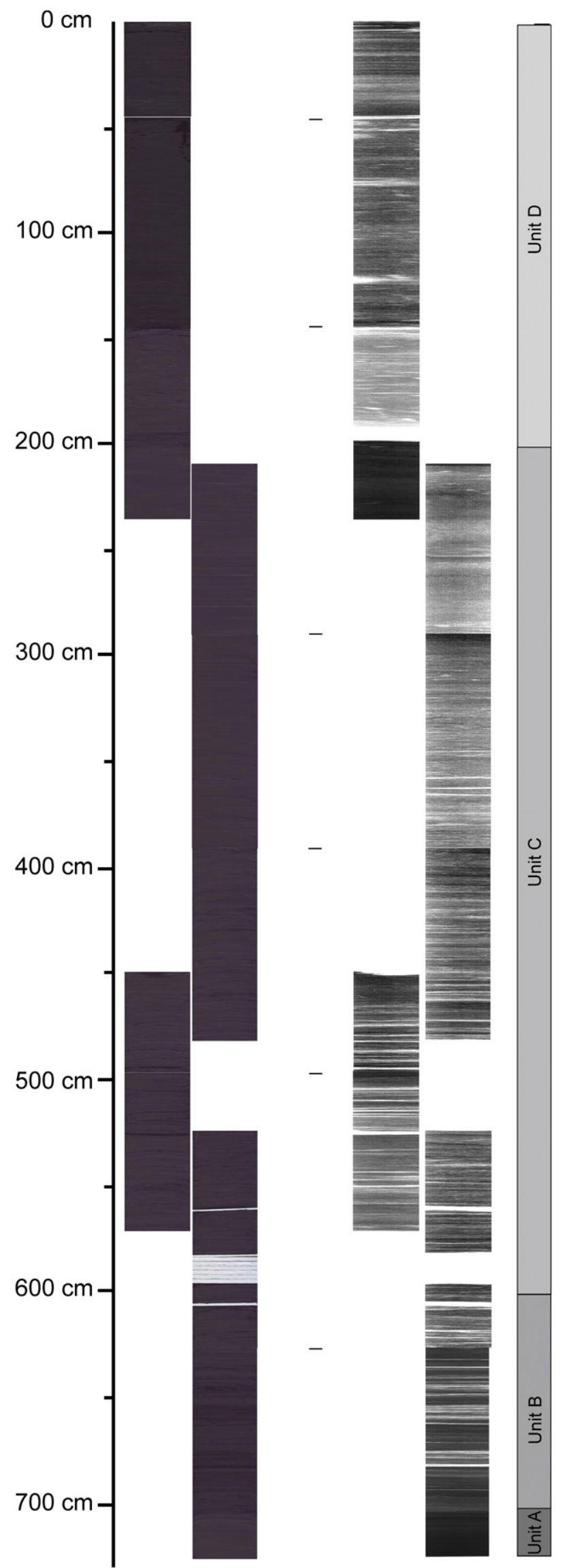

Fig. 3. Down-core high-resolution photographs (left), radiographic images (right) and lithostratigraphic units (far right) of Lake Herschel sediment core PG1967. 
boundary between unit $C$ and unit $\mathrm{D}$. A pebble of $1 \mathrm{~cm}$ in diameter is present at $198 \mathrm{~cm}$. Within unit D, minerogenic light-gray layers (about $4 \mathrm{~mm}$ thick) alternate with dark-gray organic-rich sandy layers (about $2 \mathrm{~mm}$ thick). Unit D sediment is less compact than the sediments of the units below. Dark organic-rich material is visible at $126 \mathrm{~cm}$ and between 145 and $148 \mathrm{~cm}$ depth; mollusk shells occur at 57 to $61 \mathrm{~cm}$.

\subsection{Radiography}

The positive radiographic images show a distinct change in sediment structure along the core (Fig. 3). Except for the weakly bedded and rather dense material composing unit $\mathrm{A}$, the sediments are laminated, as indicated by areas of lower and higher density. Between 700 and $350 \mathrm{~cm}$ (unit B and the lower half of unit C) the sediment core shows stronger contrast between thin layers less than $1 \mathrm{~mm}$ thick. The upper half of the core (350 cm to the top) is also layered but with less contrast between individual layers. The boundary between units $C$ and $D$ is marked by a distinct high density area below $200 \mathrm{~cm}$ and a very low density area from above $200 \mathrm{~cm}$ to the top. Besides this boundary, and apart from the described gaps in unit C, low density areas are visible at 10,70,120, and $360 \mathrm{~cm}$. Distinct low density layers are present at 530 and $690 \mathrm{~cm}$ within the layered units $\mathrm{C}$ and $\mathrm{B}$.

\subsection{Magnetic susceptibility and water content}

The MS data vary between 6.4 and 19.7 SI (Fig. 4). The unit A MS is nearly constant, ranging between 14.0 and $15.0 \mathrm{SI}$, whereas the unit $\mathrm{B}$ MS ranges from 7.3 to $13.2 \mathrm{SI}$ and exhibits the highest variability of all the core units. A step towards lower values at 480 to $500 \mathrm{~cm}$ and a general trend of declining values, from about 15.0 to $10.0 \mathrm{SI}$, with depth are notable in unit C. At the boundary between units $C$ and $D$, a significant change in MS is evident where values decrease from 14.2 to $6.4 \mathrm{SI}$; they remain at a low level $(7.2$ to $9.0 \mathrm{SI})$ in unit D.

The water content of the sediment core ranges from 5.2 to 32.3 wt.\% (Fig. 4). A low average water content of 11.2 wt.\% was measured in unit A. In unit B, values vary between $12.6 \mathrm{wt} . \%$ and 23.7 wt.\% with higher water content in organic-rich layers. The average water content in unit $\mathrm{C}$ is about $14.1 \mathrm{wt} . \%$ with values ranging from 10.7 to $16.9 \mathrm{wt} . \%$, except for a significant minimum of $5.2 \mathrm{wt} . \%$ at $570 \mathrm{~cm}$. At the transition from unit C to D a significant increase in water content was measured. With the exception of the relatively high value (32.3 wt.\%) at $190 \mathrm{~cm}$, the unit D water content is uniform, but at $21.9 \mathrm{wt} . \%$ on average it is almost twice as high as in unit C.

\subsection{Grain size distribution}

The observed 2 to $5 \mathrm{~mm}$ thick laminations are not resolved by our sampling interval of $10 \mathrm{~cm}$. Therefore, the granulometrical results integrate the laminations and general trends in sedimentological variations. According to the nomenclature used by Shephard (1954), the sediment core is dominated by clayey to sandy silt (Fig. 5). The mean grain size ranges from $5.7 \mu \mathrm{m}$ (fine silt) to $17.8 \mu \mathrm{m}$ (coarse silt) with a sandy outlier at $200 \mathrm{~cm}$ (Fig. 4). The pattern of grain-size distribution usually shows bimodal to trimodal curves with a major peak in the fine-silt fraction and a minor peak in the fine-sand fraction reflecting the observed fine lamination. There is a distinct peak of very-poorly-sorted fine sand from 200 to $201 \mathrm{~cm}$. The sediment of the whole core is poorly to very-poorly sorted (3.5 to $6.4,4.8$ on average, after Folk and Ward, 1957).

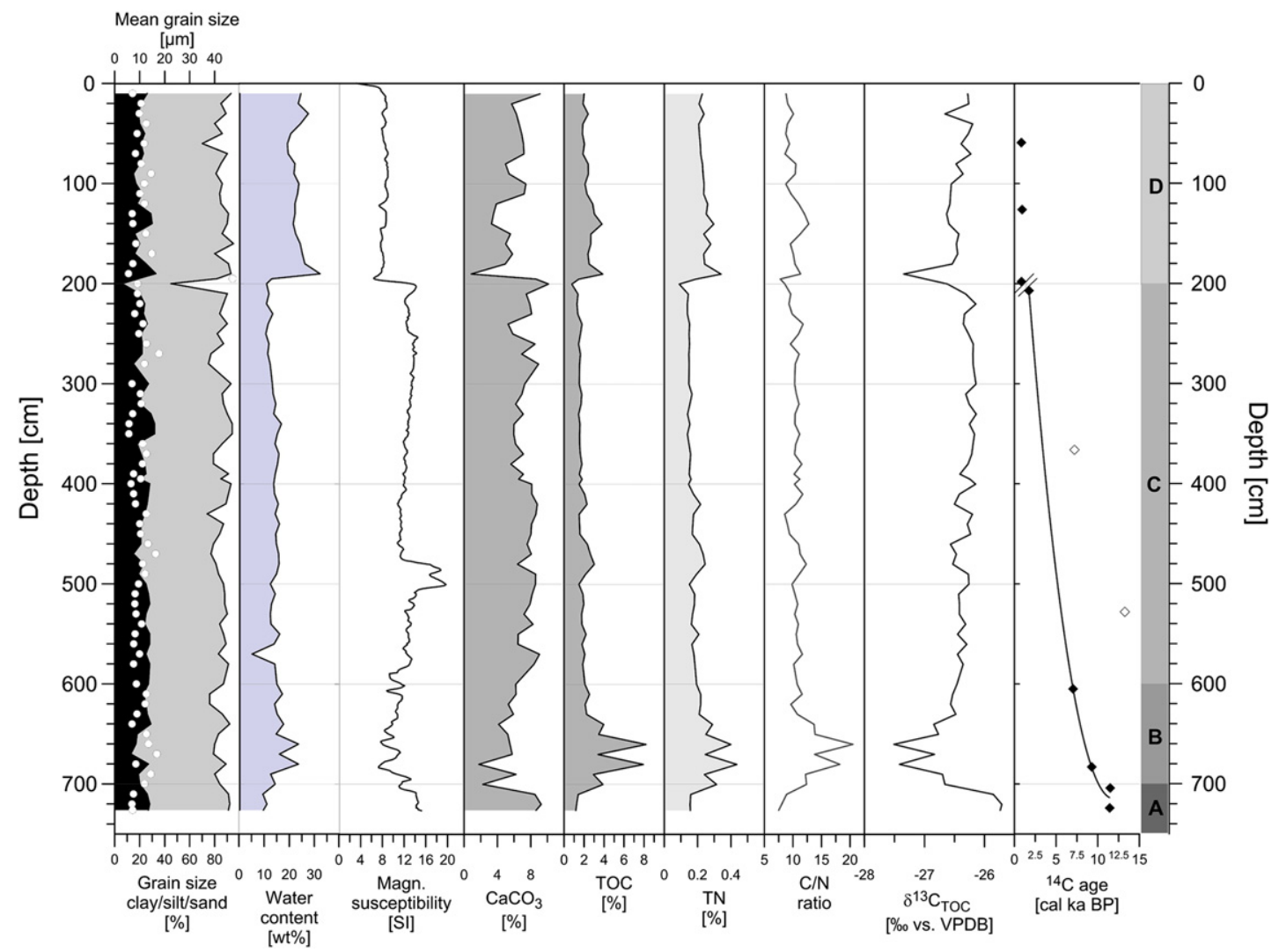

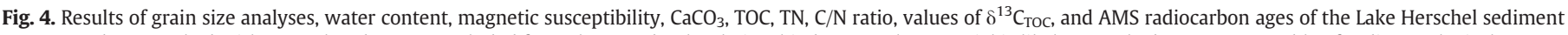

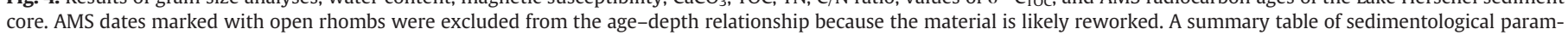
eters from lake sediment core \# PG1967 (Herschel Island, Yukon Territory) can be found in the supplementary online material to this article. 


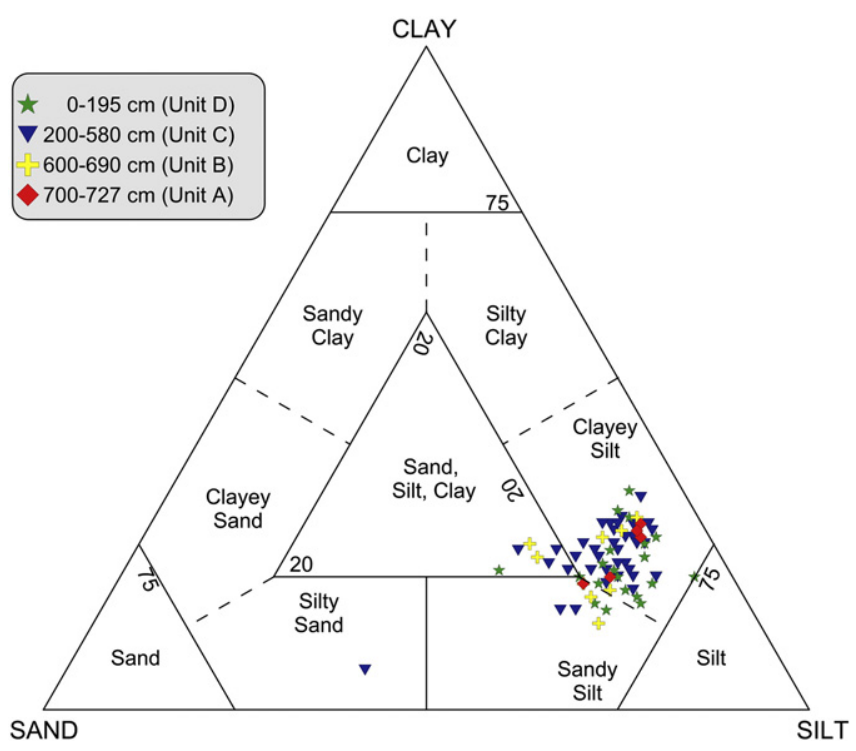

Fig. 5. Grain size characteristics from Lake Herschel sediment core displayed in a sediment triangle according to Shephard (1954).

\subsection{Biogeochemical characteristics}

In unit $\mathrm{A}$, the $\mathrm{TN}$ is $0.2 \%$, the $\mathrm{TOC}$ is $1.9 \%$, and the mean $\mathrm{C} / \mathrm{N}$ ratio is 9.2. The calculated $\mathrm{CaCO}_{3}$ content is relatively high (median $=7.2 \%$ ) in unit A. Unit B exhibits the highest content and largest variance of TN and $\mathrm{CaCO}_{3}$ values $\left(\mathrm{TN}_{\max }\right.$ of $0.4 \%, \mathrm{CaCO}_{3 \min }$ of $\left.1.8 \%\right)$. TOC content in unit $\mathrm{B}$ is between 2.1 and $8.2 \%$. C/N ratios range between 20.5 at $660 \mathrm{~cm}$ and 9.6 at $620 \mathrm{~cm}$ depth. Less variation in the biogeochemical parameters is found in unit $\mathrm{C}$. TN values are low $\left(\mathrm{TN}_{\max }\right.$ of $\left.0.2 \%\right)$ and slightly decrease upwards to the device-specific accuracy of $0.1 \%$. TOC values show minimal changes (median $=1.8 \%$ ). The $\mathrm{C} / \mathrm{N}$ ratio (median $=10.5$ ) is moderate without major variations. The $\mathrm{CaCO}_{3}$ content ranges from 5.3 to $9.1 \%$ (median $=7.5 \%$ ). Except for increases in $\mathrm{TN}$ and TOC at $430 \mathrm{~cm}$ and at 470 to $480 \mathrm{~cm}$, respectively, the values are almost constant. At the boundary between units $C$ and D (at $200 \mathrm{~cm}$ ) all biogeochemical parameters indicate a distinct change. After a decrease in TN and TOC at $200 \mathrm{~cm}(\mathrm{TN}<0.1 \%$; TOC $0.8 \%)$ an increase follows (TN $0.3 \%$; TOC 8.9\%). At this transition the $\mathrm{CaCO}_{3}$ content decreases by $9.2 \%$ (from 10.1 to $0.9 \%$ ). Unit D shows minor variations. TN varies from 0.2 to $0.3 \%$ from 140 to $170 \mathrm{~cm}$ and TOC values are between 2.4 and $3.8 \%$.

The $\delta^{13} C_{\text {TOC }}$ values from core PG1967 range between -27.5 and $-25.7 \%$, reflecting mostly a lacustrine organic carbon source deriving from $C_{3}$ photosynthesis (Meyers, 1994). In unit $A, \delta^{13} C_{\text {TOC }}$ values are between -26.7 and $-25.7 \%$. $\delta^{13} \mathrm{C}_{\text {TOC }}$ values in unit $\mathrm{B}$ have a mean value of $-26.8 \%$ with a maximum of $-26.5 \%$ at 600 to $610 \mathrm{~cm}$ depth (upper boundary of unit B) and minima of $-27.5 \%$ ond $-27.4 \%$ at $660 \mathrm{~cm}$ and $680 \mathrm{~cm}$ (lower boundary of unit B). Almost no $\delta^{13} \mathrm{C}_{\mathrm{TOC}}$ variation was found in unit C; values range between -26.6 and $-26.1 \%$. The boundary between units $C$ and $D$ coincides with a decrease in $\delta^{13} C_{\mathrm{TOC}}$ values from -26.7 to $-27.3 \%$ at $190 \mathrm{~cm}$. In unit $\mathrm{D}$ the $\delta^{13} \mathrm{C}_{\mathrm{TOC}}$ values range between -27.3 and $-26.2 \%$.

\subsection{Geochronology}

An age-depth relationship was established using eight out of ten AMS radiocarbon dates from the sediment core (Fig. 4, Table 2). A squared regression model $\left(\mathrm{y}=-5.1721 \cdot 10^{-6} \mathrm{x}^{2}+0.1205 \mathrm{x}+12.1237 ; \mathrm{r}^{2}=\right.$ 0.99 ) was used for age interpolation between units $A, B$, and C. No interpolation was applied between individual unit D datings as they show concordant ages of about 900 years BP within two standard deviations. According to the dating results, the sediment record covers the last $\sim 11,500$ years. The basal part of the sediment sequence (unit A) was deposited between $\geq 11.5$ and 10.0 cal ka BP (Fig. 4). Unit B covers the time span from 10.0 to 7.0 cal ka BP. Unit C was dated at 7.0 to 1.8 cal ka BP. Finally, unit D represents the most recent 900 years, indicating rapid sedimentation of the uppermost $\sim 200 \mathrm{~cm}$. Dating of organic macro remains directly below and above the lithostratigraphic boundary between units $\mathrm{C}$ and $\mathrm{D}$ revealed a hiatus between 1.8 and $0.9 \mathrm{cal}$ ka BP, probably due to lake drainage or slumping of bankside material. Both hypotheses are addressed in the Discussion section. Two age determinations of $\sim 13.2 \mathrm{cal}$ ka BP and $7.2 \mathrm{cal} \mathrm{ka} \mathrm{BP}$ at $525 \mathrm{~cm}$ and $367 \mathrm{~cm}$, respectively, yielded anomalously old dates compared to ambient ages. These dates are considered to originate from material that has been reworked and are not used for further interpretation. Redeposition of terrestrial organic matter by slumping of bankside material could cause the deviation from superposition, which is quite common in sediments of thermokarst lakes (Murton, 1996) that formed by thaw subsidence and were influenced by active shore erosion within older deposits (Wetterich et al., 2009).

\section{Discussion}

\subsection{Evolution of Lake Herschel}

An extensive Late Wisconsin advance of the LIS towards the northern Yukon Territory and Northwest Territories is documented by Dyke et al. (2002) and Kennedy et al. (2010). Relatively young ages are assumed for this last regional advance (Zazula et al., 2009: 20.0 cal ka BP; Mackay and Dallimore, 1992: 18.0 to 17.0 cal ka BP; Murton et al., 2007: 17.0 to 15.0 cal ka BP; and Fritz et al., 2012a,b: $\sim 16.0$ cal ka BP). Glacial push-up of pre-existing ice-rich permafrost formed the Herschel ridge and incomplete glaciation left behind a landscape with high relief energy and abundant basal glacier ice among other types of massive ground ice. This is illustrated in Fig. 7a as the pre-lake stage.

\subsubsection{Initial lake phase}

Thermokarst in general and thermokarst lake development in particular commenced after deglaciation. Rapidly rising air temperatures at the Pleistocene-Holocene transition led to the melt-out of massive ground ice, accompanied by surface subsidence and water pooling in depressions underlain by permafrost and a semi-permeable clayey diamicton. We consider unit A to represent the initial phase of lake genesis, and thus, the minimum age of thermokarst onset is at or prior to 11.5 cal ka BP (Fig. 7b). This is in agreement with studies from the northern Yukon and Northwest Territories where the frequency distribution of basal dates from thaw lake sediments and in-situ rootlets from the base of a regional palaeo-active layer indicate a thermokarst onset at around 10 ka BP (i.e. 11.7 to 11.2 cal ka BP) (Rampton, 1974, 1982, 1988; Mackay, 1978; Burn, 1997; Murton et al., 1997). Herschel Island is highly susceptible to thermokarst processes and thermal erosion (Mackay, 1959; Lantuit and Pollard, 2008), as indicated by the occurrence of numerous retrogressive thaw slumps at coastal sites. This fact is due to the widespread occurrence of ice-rich permafrost (Bouchard, 1974), near-surface ground ice (Burn and Zhang, 2009), and large bodies of massive ice to depths of more than 30 m below surface (Pollard, 1990; Fritz et al., 2011).

Since Lake Herschel is currently the largest lake on Herschel Island, the site was particularly susceptible to ground ice melting. Surface subsidence was likely followed by the accumulation of water in an initial depression within a landscape of undulating morphology. Massive ground ice bodies of nearly pure ice are known from permafrost outcrops along the coast (Pollard, 1990; Moorman et al., 1996; Fritz et al., 2011). Herschel Island is mainly composed of a frozen marine and clayey diamicton (Mackay, 1959; Bouchard, 1974; Fritz et al., 2012b). Therefore, suitable preconditions for pooling of water are provided by this compact semi-permeable to impermeable basal 
Table 2

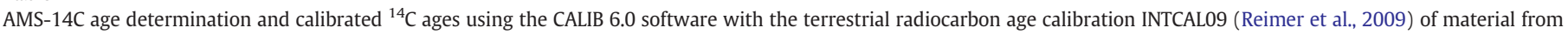
Lake Herschel sediment core PG1967.

\begin{tabular}{|c|c|c|c|c|c|c|c|}
\hline $\begin{array}{l}\text { Core depth } \\
(\mathrm{cm})\end{array}$ & Dated material & $\begin{array}{l}\text { Mass } \\
(\mathrm{mg} \mathrm{C})\end{array}$ & $\begin{array}{l}\delta^{13} \mathrm{C} \\
(\%)\end{array}$ & $\begin{array}{l}\text { Uncalibrated }{ }^{14} \mathrm{C} \text { age } \\
\text { (yrs BP) }\end{array}$ & $\begin{array}{l}\text { Calibrated } 2 \sigma \text {-age range } \\
\text { (cal yrs BP) }\end{array}$ & 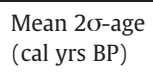 & Lab. no. ${ }^{a}$ \\
\hline $57-61$ & Mollusc shell (Pisidium sp.) & 0.2 & -8.4 & $920 \pm 40$ & $759-923$ & 840 & Poz-36423 \\
\hline 126 & Undefined moss and wood fragments & $>1$ & -27.9 & $985 \pm 30$ & $895-959$ & 930 & Poz-36425 \\
\hline 197-199 & Drapanocladus sp. & 0.5 & -32.0 & $950 \pm 35$ & $788-930$ & 860 & Poz-49515 \\
\hline $206-208$ & Vascular plant fragments & 0.7 & -25.7 & $179 \pm 30$ & $1687-1818$ & 1750 & Poz-49516 \\
\hline $366-367$ & Undefined moss fragments & $>1$ & -27.8 & $623 \pm 40^{\mathrm{b}}$ & 7144-7255 & 7200 & Poz-36426 \\
\hline 528 & Vascular plant fragments & $>1$ & -27.4 & $11,370 \pm 70^{\mathrm{b}}$ & $13,111-13,363$ & 13,240 & Poz-36427 \\
\hline $604-606$ & Homalothecium nitens & 0.6 & -29.9 & $6160 \pm 50$ & 6906-7175 & 7040 & Poz-49517 \\
\hline 683 & Undefined wood fragments & $>1$ & -30.4 & $8290 \pm 50$ & $9127-9438$ & 9280 & Poz-36428 \\
\hline $703-705$ & Homalothecium nitens, Carex sp. & 0.5 & -34.1 & $9990 \pm 60$ & $11,252-11,717$ & 11,490 & Poz-49519 \\
\hline $723-725$ & Undefined wood fragments & $>1$ & -31.9 & $9980 \pm 50$ & $11,253-11,633$ & 11,440 & Poz- 49520 \\
\hline
\end{tabular}

Poz $=$ Poznan Radiocarbon Laboratory.

b Not used for reasons seen in the text.

material. Thermokarst lakes will not develop if the warmed water percolates through the ground and only deepens the active layer (Harris, 2002). But if the water from melting ground ice or snow pools in basins and remains on the surface, absorption of incoming radiation is increased compared to the surrounding surface. Increased thawing of ice-rich permafrost and thaw subsidence form a positive feedback mechanism (Harris, 2002).

\subsubsection{Early Holocene lake phase}

The Pleistocene-Holocene transition was a period of rapid environmental change. In this context, the evolution of Lake Herschel started as a thermokarst basin. Thermokarst development likely peaked during the HTM, which is a post-glacial warm period with warmer-than-modern summer air temperatures lasting from about 10.6 to 6 cal ka BP in northwestern Canada (Kaufman et al., 2004). Maximum Holocene summer air temperatures caused maximum active-layer deepening accompanied by intense ground ice melt-out and thaw subsidence (e.g. Burn, 1997). Lateral lake basin expansion caused shore-line erosion which in turn led to higher lake productivity due to increased nutrient input (Kokelj et al., 2005).

The growing Lake Herschel basin was possibly characterized by a fluctuating lake level (Fig. 7c) and alternation in the relative inputs of lacustrine vs. terrestrial organic matter, as evident from the variable $\mathrm{C} / \mathrm{N}$-ratios and $\delta^{13} \mathrm{C}_{\mathrm{TOC}}$ values (Fig. 6). High bioproductivity inferred by up to $0.4 \% \mathrm{TN}$ and $8.2 \%$ TOC content could be explained by a shorter duration of lake-ice coverage and a longer growing season during the early Holocene warming. Similar characteristics (MS, water content, $\mathrm{C} / \mathrm{N}$ ) of lake sediments deposited during the HTM are described for Lake CF3 (Briner et al., 2006) and for Brother Lake and Fog Lake (Francis et al., 2006) on Baffin Island (Canadian Arctic

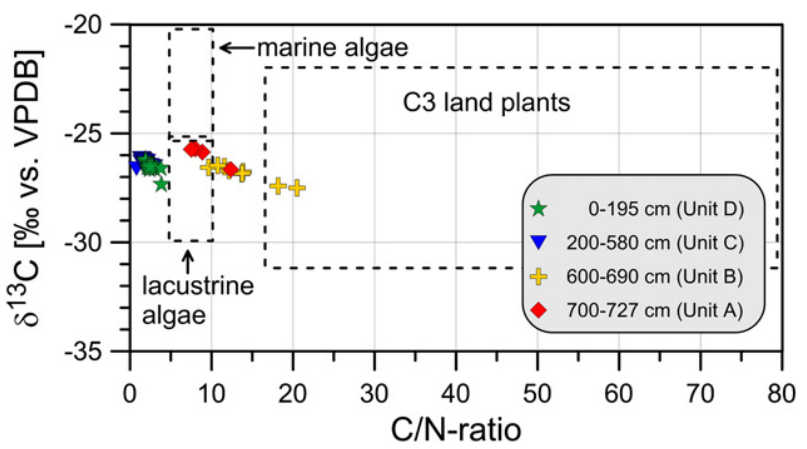

Fig. 6. $\delta^{13} \mathrm{C}_{\mathrm{TOC}}$ values and $\mathrm{C} / \mathrm{N}$-ratios of bulk organic matter from units $\mathrm{A}$ (red diamonds), B (yellow crosses), C (blue triangles) and D (green stars) presented relative to the ranges for organic matter produced by $C_{3}$ land plants, marine algae, and lacustrine algae (according to Meyers, 1994 and Meyers and Lallier-Verges, 1999).
Archipelago). We suggest that the Lake Herschel became deep enough ( $>\sim 2 \mathrm{~m}$ depth) to avoid freezing to the bottom in winter. The heat storage effect of an unfrozen water body leads to continuous thawing of underlying permafrost and creates a talik (Fig. 7c), which is a layer or body of unfrozen ground within permafrost that forms due to a local anomaly in thermal, hydrological, hydrogeological, or hydrochemical conditions (Van Everdingen, 2005). Any disturbance of the heat balance results in further permafrost thawing and deepening of the thermokarst lake basin. Additionally, the movement of water by wind and wave action can further contribute to thawing and shoreline erosion.

\subsubsection{The mid Holocene thermokarst lake phase}

We consider a dynamic equilibrium of thermokarst lake development between 7.0 and $1.8 \mathrm{cal} \mathrm{ka} \mathrm{BP.} \mathrm{The} \mathrm{lake} \mathrm{and} \mathrm{the} \mathrm{talik} \mathrm{steadily} \mathrm{ex-}$ panded into ambient ice-rich terrain through shoreline erosion and an increase of aquatic accommodation space (Fig. 7d). The sedimentological parameters of unit $\mathrm{C}$ do not indicate distinct events in terms of sediment supply or lake level fluctuations. The invariability of measured parameters (Fig. 4) reflects stable accumulation conditions with a uniform and likely lacustrine source of organic carbon (Fig. 6). A growing distance between the shoreline and our coring location might have occurred over time with lake expansion. Therefore, a directed or abrupt sediment input close to shore changed into a more continuous and diffuse input of particles as the coring location became more distal to the sediment source with lake expansion (Murton, 1996).

\subsubsection{The final late Holocene lake stage}

Unit D represents accumulation during the last 900 years (Fig. 7f). This uppermost unit is characterized by sediments with higher organic matter content as indicated by increased TOC and water contents, and by decreased MS and bulk density (Fig. 4). Here, depositional conditions differ significantly from those of the previous stage. We consider two hypotheses to explain the facies change at the transition between units $C$ and $D$ that left behind a hiatus between 1.8 and 0.9 cal ka BP (Fig. 7e):

(1) Hiatus hypothesis: the lake dried out or drained, causing a hiatus in sedimentation.

(2) Slumping hypothesis: allochthonous slumping disturbed the continuous sedimentation.

5.1.4.1. Hiatus hypothesis. A hiatus between 1.8 and 0.9 cal ka BP might be explained by subaerial sedimentation after the lake dried out or rapidly drained. In this case, the last 900 years of lake development might have happened as follows. Due to increased evaporation or subsidence, reactivation, and modified inflow or drainage conditions, the water level fell and caused a higher morphological gradient. 


\section{Succession of Lake Herschel}

a) Pre-lake stage

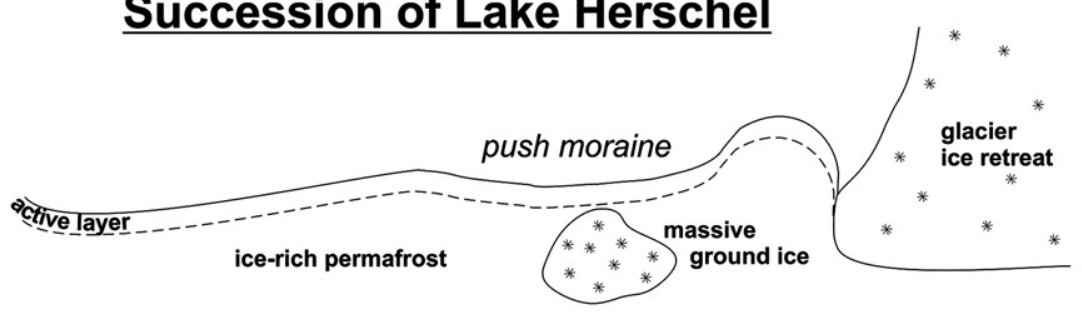

b) Initial lake stage

$\geq 11.5-10.0$ cal ka BP $(\approx$ Unit $A)$

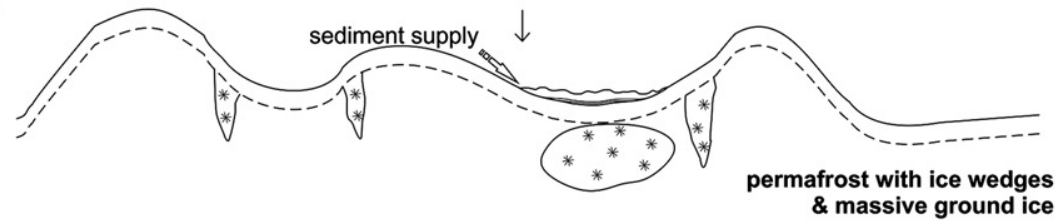

c) Early Holocene lake stage

10.0-7.0 cal ka BP (HTM) (Unit B)

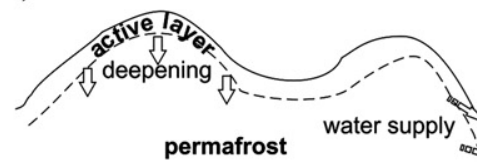

d) Mid Holocene lake stage

$\sim 7.0-1.8$ cal ka BP (Unit C)

$\downarrow$

$\&$ massive ground ice

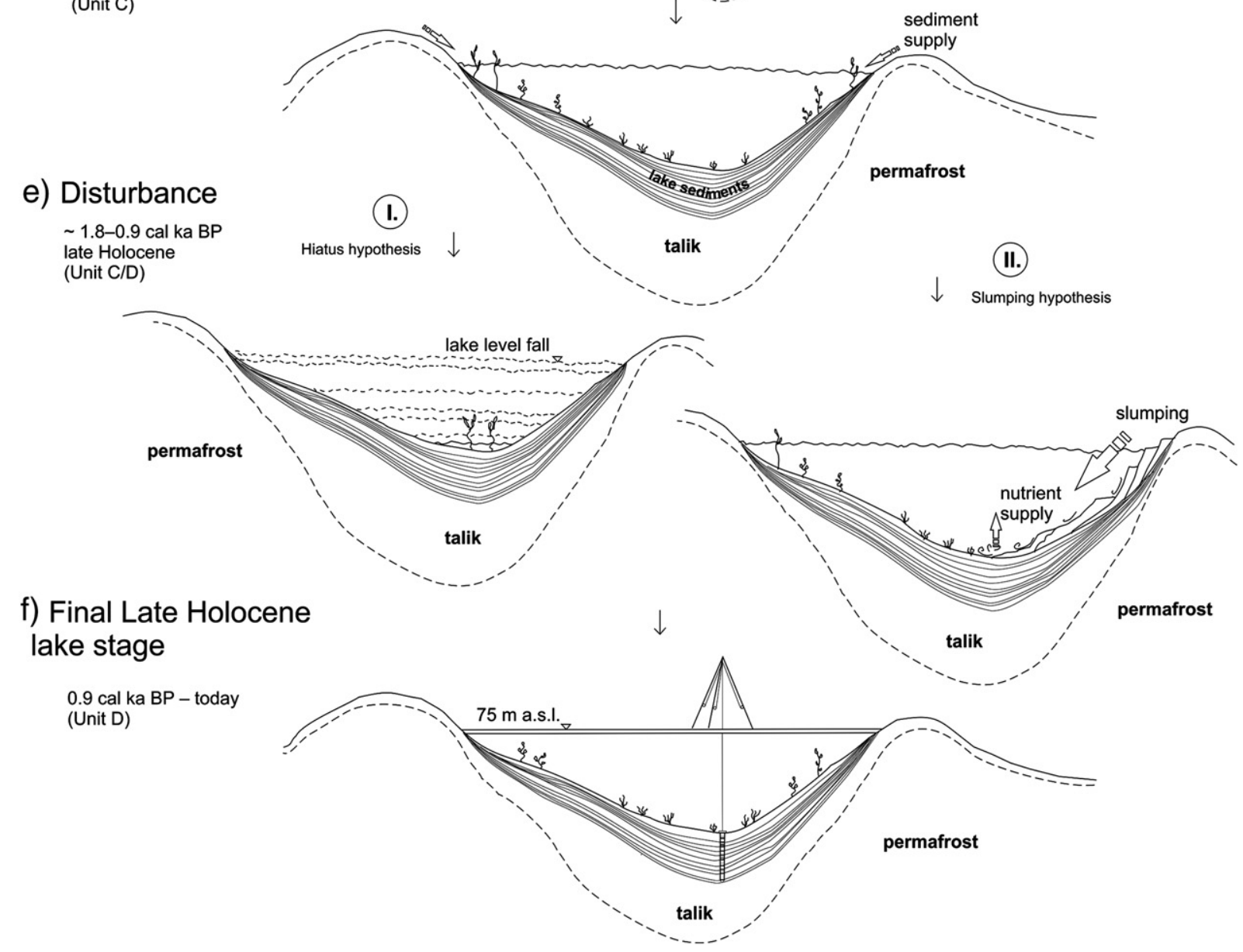

Fig. 7. Schematic synthesis of the evolution of thermokarst lakes on Herschel Island under conditions of ice-rich permafrost as discussed in this paper.

This in turn led to increased transport energy allowing coarser sediments to become deposited as recognized at $190 \mathrm{~cm}$ core depth. The lake at $0.9 \mathrm{cal}$ ka BP was either shallow with a rising lake level that continued to rise until today, or the lake basin dried out or drained completely causing a hiatus (Fig. 7e). Thermokarst lakes can drain catastrophically within a few hours due to melt-out of ground 
ice (Mackay, 1990; Jones et al., 2011). For example, lakes on northern Richards Island (Northwest Territories) drain because they are breached shorelines that are retreating due to coastal erosion (Dallimore et al., 2000). However, the mechanisms and interrelations of thermokarst lake growth, expansion, and eventual drainage are still not completely understood (French, 2007).

A distinct organic-rich layer directly above the minerogenic layer at the transition from unit $\mathrm{C}$ to $\mathrm{D}$ supports the drainage hypothesis. A lake level fall could have produced the higher energy required to transport coarser sediment grains, followed by an increasing productivity of lacustrine organisms in a shallow small lake; and finally, the re-start of lacustrine deposition may have induced the accumulation of nutrientand organic-rich layers in unit D. The high water content of up to 32.3 wt.\% coupled with the low density in unit D indicates a completely different depositional environment and high accumulation rates compared with units $\mathrm{C}$ and $\mathrm{B}$.

5.1.4.2. Slumping hypothesis. A slumping hypothesis is supported by differences in water content, $\mathrm{MS}, \mathrm{CaCO}_{3}, \mathrm{TOC}, \mathrm{TN}, \mathrm{C} / \mathrm{N}$ ratio, and $\delta^{13} C_{\text {TOC }}$ values between units $C$ and D (Fig. 4). According to Kokelj et al. (2002), the geomorphological activity of mass movements could promote salt concentration due to evaporation from the surface of exposed sediments. Slumping provides not only sediments but also nutrients and soluble elements that could cause higher primary productivity, as indicated in unit D by the relatively high TN (up to $0.3 \%$ ) and TOC content (up to 3.9\%). Organic-rich layers are also less dense compared with minerogenic sediments, as visible in the radiographic images (Fig. 3). This probably explains the higher water content measured in organic-rich layers, especially in the thick organic-rich horizon at $190 \mathrm{~cm}$ covering the coarser sand layer at the boundary between unit $\mathrm{C}$ and unit $\mathrm{D}$.

Expanding thermokarst lakes are often characterized by frequently collapsing shore lines (Burn and Smith, 1990). A corresponding inactive landslide site, currently stabilized and vegetated, is located east of the drilling location on the eastern shore (Fig. 2). Higher precipitation and higher pore water pressures in surface sediments could have caused mass wasting processes and thaw slumps along lake shore slopes (Fig. 7e). Increasing effective moisture during the late Holocene is reported from Marcella Lake in the southwest Yukon Territory (Anderson et al., 2007). The abrupt occurrence of testate amoebae indicating freshwater to slightly brackish conditions in thermokarst lakes on Richards Island indicates eutrophic conditions within the last 3000 years (Dallimore et al., 2000). According to Dallimore et al. (2000), higher productivity does not necessarily indicate a warming climate trend but could have been caused by changes in local limnological conditions due to morphological instability of thermokarst lakes and nutrient input (Kokelj et al., 2005). The last 900 years of thermokarst lake history demonstrate that local events such as slumping or drainage are most likely responsible for facies changes during the late Holocene.

\subsection{Palaeoenvironmental implications of the Lake Herschel record}

The Herschel ridge was formed by glacier-ice thrust and the responsible ice advance has recently been timed to as late as $\sim 16 \mathrm{cal}$ ka BP (Fritz et al., 2012b). Nevertheless, the Herschel area remained ice-free during the late glacial period and was affected by periglacial processes under harsh continental climate conditions in close vicinity to the LIS (Rampton, 1982; Schweger, 1997; Fritz et al., 2012b).

Northwest Canada experienced the HTM between approximately 11.6 and $6.0 \mathrm{cal} \mathrm{ka} \mathrm{BP}$ and the Yukon Territory and the westernmost Mackenzie Delta area experienced warmer-than-present summer temperatures by that time (Ritchie et al., 1983; Ritchie, 1984; Kaufman et al., 2004). Palaeoenvironmental controls included orbital, climatic and geographical effects: (1) high precessional forcing resulted in summer insolation at $60^{\circ} \mathrm{N}$ of $10 \%$ above modern conditions; (2) atmospheric water vapor content increased due to postglacial warming; (3) reduced snow and ice cover caused positive albedo-ground temperature feedbacks (Kaufman et al., 2004); and (4) a lower glacio-eustatic sea level displaced the coastline northward leading to greater continentality (Burn, 1997).

Rapid climate warming in the western Canadian Arctic at about 11.0 cal ka BP is indicated by a northwards-moving tree line (e.g. Ritchie and Hare, 1971; Spear, 1993; Szeicz and MacDonald, 2001; Bigelow et al., 2003). Pollen records from South Lake (Northwest Territories; Rühland et al., 2009) and Hanging Lake (northern Yukon Territory; Cwynar, 1982) provide evidence for a pronounced HTM. Cwynar (1982) inferred wet heath communities in the period from 11.1 to 8.9 cal ka BP as a response to a warmer and wetter climate. Between 11.0 and $8.5 \mathrm{cal}$ ka BP climate conditions progressively ameliorated and could have induced a period of thermokarst development (French, 1974; Ritchie et al., 1983; Ritchie, 1984; Rampton, 1988; Murton, 2001; Fritz et al., 2012b). Lake Herschel is probably one of the numerous lakes along the western Arctic coast that initiated as a result of the HTM. According to Rampton (1982, 1988), the formation of thermokarst lakes along the Yukon Coastal Plain and the Tuktoyaktuk Coastlands peaked between 11.6 and 10.3 cal ka BP. Murton $(1996,2001)$ and Dallimore et al. (2000) assigned the onset of thermokarst lake development on the Tuktoyaktuk Coastlands to the HTM. At the same time, several lakes in the Yukon Territory seem to have dried out (Pienitz et al., 1992). According to Kaufman et al. (2004), local HTM summer temperatures in the western Arctic regions were on average $1.6^{\circ} \mathrm{C}( \pm 0.8)$ higher than the 20th century mean annual air temperatures. The HTM was time-transgressive because Alaska and the western Canadian Arctic were most distant from the waning LIS and therefore warmed earlier $(11.3 \pm 1.5 \mathrm{cal} \mathrm{ka}$ BP) than continental Canada and the Canadian Arctic Archipelago ( $7.3 \pm 1.6 \mathrm{cal} \mathrm{ka} \mathrm{BP})$, which were still under the cooling influence of the LIS (Kaufman et al., 2004).

Between 11.6 and 5.6 cal ka BP several plant taxa indicating wetter and warmer climate conditions (Populus, Typha, Myrica) spread north of their present ranges, and Picea forest advanced $75 \mathrm{~km}$ beyond the present tree line on the Tuktoyaktuk Peninsula (Ritchie and Hare, 1971; Cwynar, 1982; Ritchie et al., 1983; Spear, 1993). Near-modern temperatures were reached between 6.7 and $5.6 \mathrm{cal}$ ka BP (Cwynar and Spear, 1995; Kaufman et al., 2004). Cooler and moister conditions have prevailed since the middle Holocene at $\sim 6.0$ cal ka BP, as indicated by increases of green alder (Alnus crispa) and black spruce (Picea mariana) pollen percentages in the Yukon (Cwynar and Spear, 1995; Fritz et al., 2012a).

The continuous Holocene sedimentation into Lake Herschel progressed uninterrupted until about $1.8 \mathrm{cal}$ ka BP. This may account for the absence of strong changes in depositional conditions or the low sensitivity of the lake to environmental change. Wetter conditions at this time are evident from the southern Yukon Territory (Pienitz et al., 2000; Anderson et al., 2007), but no significant changes in climate conditions in the Mackenzie Delta and the northern Yukon Territory have been identified from pollen records representing the last 6.0 cal ka BP (Ritchie, 1984; Fritz et al., 2012a). The majority of thermokarst lakes in the Mayo area (central Yukon) have been expanding since their inception a few hundred years ago and warm summers, as in 1989, could have reactivated slumping even along formerly stable shorelines (Burn and Smith, 1990). Comparing the late Holocene lake evolution on Herschel Island with the early Holocene development indicates that thermokarst lake development is not solely controlled by global and regional climate dynamics, but is also driven by site-specific factors like permafrost dynamics, geomorphology and local climate effects.

\section{Conclusions}

Lake sediments from Herschel Island represent the northernmost palaeoenvironmental record of thermokarst activity from the Yukon Territory. A multidisciplinary approach allowed us to reconstruct 
thermokarst lake evolution since the early Holocene on a late Wisconsin push moraine. The following conclusions can be drawn from this study:

1. Thermokarst lake development started around $11.5 \mathrm{cal}$ ka BP on Herschel Island and probably at the same time in other parts of the northern Yukon Territory.

2. The onset of Lake Herschel correlates with the Holocene Thermal Maximum and is therefore in good agreement with thermokarst lake formation in other parts of the western Canadian Arctic.

3. Lake basin development on a push moraine is apparently the result of ground subsidence due to thawing of ice-rich permafrost and melt-out of massive ground ice, which is abundant in areas of incomplete glaciation like the formerly glaciated parts of the Yukon Coastal Plain.

4. Positive feedback mechanisms operating between the heat capacity of the growing water body and the ice-rich permafrost catchment likely led to thermokarst lake growth during the early and middle Holocene.

Abrupt events like sudden lake drainage or collapsing lake shores may leave their imprints in the sedimentary record. Though thermokarst lake sediments have a high preservation potential and may capture regional environmental change, this study also shows that site-specific processes can disturb continuous sedimentation under otherwise fairly constant climate conditions. This study provides a record of thermokarst lake dynamics on a heterogenic push moraine where geomorphological processes are driven by relief energy and high ground ice content.

\section{Acknowledgments}

We wish to express our thanks to the Yukon Territorial Government, the Yukon Parks (Herschel Island Qiqiktaruk Territorial Park), and especially to chief ranger R. Gordon. The authors acknowledge the support of the Polar Continental Shelf Program (PCSP/ÉPCP) and the Aurora Research Institute (ARI, Inuvik) for the field component. This study was partly funded by the German Federal Ministry of Education and Research (BMBF, Project No. CAN 09/001) and by a doctoral fellowship awarded to M. Fritz by the German Federal Environmental Foundation (DBU). Field support was provided by G. Müller, G. De Pascale, and S. McLeod. Analytical work was supported with $\delta^{13} \mathrm{C}_{\mathrm{TOC}}$ determination by B. Plessen (GeoForschungsZentrum Potsdam, Germany), measurement of magnetic susceptibility by C. Gebhardt (AWI Bremerhaven, Germany), radiographic images and photographs by V. Wennrich (University of Cologne, Germany), plant macrofossil determination by $\mathrm{R}$. Zibulski (AWI Potsdam, Germany), D. Michaelis and A. Teltewskoi (University of Greifswald, Germany) and general laboratory assistance by U. Bastian (AWI Potsdam, Germany). We thank N.J. Couture (Geological Survey of Canada), P. Frenzel (University of Jena, Germany), and S. Lorenz (University of Greifswald, Germany) for discussions on earlier versions of the manuscript and C. O'Connor (UAF, Fairbanks, Alaska) for language correction. Two anonymous reviewers and the editor (T. Corrège) are thanked for constructive comments that helped to improve the paper.

\section{References}

Anderson, L., Abbott, M.B., Finney, B.P., Burns, S.J., 2007. Late Holocene moisture balance variability in the southwest Yukon Territory, Canada. Quaternary Science Reviews $26,130-141$.

Bigelow, N.H., Brubaker, L.B., Edwards, M.E., Harrison, S.P., Prentice, I.C., Anderson, P.M., Andreev, A.A., Bartlein, P.J., Christensen, T.R., Cramer, W., Kaplan, J.O., Lozhkin, A.V., Matveyeva, N.V., Murray, D.F., McGuire, A.D., Razzhivin, V.Y., Ritchie, J.C., Smith, B., Walker, D.A., Gajewski, K., Wolf, V., Holmqvist, B.H., Igarashi, Y., Kremenetskii, K., Paus, A., Pisaric, M.F.J., Volkova, V.S., 2003. Climate change and Arctic ecosystems: 1. Vegetation changes north of $55^{\circ} \mathrm{N}$ between the last glacial maximum, midHolocene, and present. Journal of Geophysical Research-Atmospheres 108 (D19), 8170. http://dx.doi.org/10.1029/2002JD002558.
Bouchard, M., 1974. Surficial Geology of Herschel Island, Yukon Territory. M.Sc. thesis University of Montréal (70 pp.).

Bradley, R.S., England, J.H., 2008. The younger dryas and the sea of ancient ice. Quaternary Research 70, 1-10.

Briner, J.P., Michelutti, N., Francis, D.R., Miller, G.H., Axford, Y., Wooller, M.J., Wolfe, A.P. 2006. A multi-proxy lacustrine record of Holocene climate change in northeastern Baffin Island, Arctic Canada. Quaternary Research 65, 431-442.

Burn, C.R., 1997. Cryostratigraphy, paleogeography, and climate change during the early Holocene warm interval, western Arctic coast, Canada. Canadian Journal of Earth Sciences 34, 912-925.

Burn, C.R., 2009. After whom is Herschel Island named? Arctic 62, 317-323.

Burn, C.R., Smith, M.W., 1990. Development of thermokarst lakes during the Holocene at sites near Mayo, Yukon Territory. Permafrost and Periglacial Processes 1, $161-176$.

Burn, C.R., Zhang, Y, 2009. Permafrost and climate change at Herschel Island (Qikiqtaruq), Yukon Territory, Canada. Journal of Geophysical Research 114 , F02001. http://dx.doi.org/10.1029/2008jf001087.

Carter, L.D., 1988. Loess and deep thermokarst basins in arctic Alaska. Fifth International Conference on Permafrost. Tapir, Trondheim Norway.

Croudace, I.W., Rindby, A., Rothwell, R.G., 2006. ITRAX: description and evaluation of a new multi-function X-ray core scanner. In: Rothwell, R.G. (Ed.), New Techniques in Sediment Core Analysis: Geological Society, London, Special Publications, 267, pp. 51-63.

Cwynar, L.C., 1982. A Late-Quaternary vegetation history from Hanging Lake, Northern Yukon. Ecological Monographs 52 (1), 1-24.

Cwynar, L.C., Spear, W., 1995. Paleovegetation and paleoclimatic changes in the Yukon at 6 ka BP. Géographie physique et Quaternaire 49 (1), 29-35.

Czudek, T., Demek, J., 1970. Thermokarst in Siberia and its influence on the development of lowland relief. Quaternary Research 1, 103-120.

Dallimore, A., Schröder-Adams, C.J., Dallimore, S.R., 2000. Holocene environmental history of thermokarst lakes on Richards Island, Northwest Territories, Canada: thecamoebians as paleolimnological indicators. Journal of Paleolimnology 23, 261-283.

de Krom, V., 1990. A Geomorphic Investigation of Retrogressive Thaw Slumps and Active Layer Slides on Herschel Island, Yukon Territory. M.Sc. thesis McGill University, Montreál (157 pp.).

Dyke, A.S., Prest, K., 1987. Late Wisconsinan and Holocene history of the Laurentide Ice Sheet. Géographie physique et Quaternaire 41 (2), 237-263.

Dyke, A.S., Andrews, J.T., Clark, P.U., England, J.H., Miller, G.H., Shaw, J., Veilette, J.J., 2002. The Laurentide and Innuitian ice sheets during the Last Glacial Maximum. Quaternary Science Reviews 21, 9-31.

Folk, R.L., Ward, W.C., 1957. Brazos River bar, a study in the significance of grain-size parameters. Journal of Sedimentary Petrology 27, 3-27.

Francis, D.R., Wolfe, A.P., Walker, I.R., Miller, G.H., 2006. Interglacial and Holocene temperature reconstruction based on midge remains in sediments of two lakes from Baffin Island, Nunavut, Arctic Canada. Palaeogeography, Palaeoclimatology, Palaeoecology 236, 107-124.

French, H.M., 1974. Active thermokarst processes, eastern Banks Island, Western Canadian Arctic. Canadian Journal of Earth Sciences 11, 785-794.

French, H.M., 2007. The Periglacial Environment, third ed. John Wiley \& Sons Ltd., London (458 pp.)

Fritz, M., Wetterich, S., Meyer, H., Schirrmeister, L., Lantuit, H., Pollard, W.H., 2011. Origin and characteristics of massive ground ice on Herschel Island (western Canadian Arctic) as revealed by stable water isotope and hydrochemical signatures. Permafrost and Periglacial Processes 22, 26-38.

Fritz, M., Herzschuh, U., Wetterich, S., Lantuit, H., De Pascale, G.P., Pollard, W.H., Schirrmeister, L., 2012a. Late glacial and Holocene sedimentation, vegetation, and climate history from easternmost Beringia (northern Yukon Territory, Canada). Quaternary Research 78, 549-560.

Fritz, M., Wetterich, S., Schirrmeister, L., Meyer, H., Lantuit, H., Preusser, F., Pollard, W.H., 2012b. Eastern Beringia and beyond: Late Wisconsinan and Holocene landscape dynamics along the Yukon Coastal Plain, Canada. Palaeogeography, Palaeoclimatology, Palaeoecology 319 (320), 28-45.

Harris, S.A., 2002. Causes and consequences of rapid thermokarst development in permafrost or glacial terrain. Permafrost and Periglacial Processes 13, 237-242.

Hill, P.R., Mudie, P.J., Moran, K., Blasco, S.M., 1985. A sea-level curve for the Canadian Beaufort Shelf. Canadian Journal of Earth Sciences 22, 1383-1393.

Hopkins, D.M., Kidd, J.G., 1988. Thaw lake sediments and sedimentary environments. Fifth International Conference on Permafrost, Proceedings, Vol. 1, pp. 790-795. Tapir, Trondheim.

Irvine, F., Cwynar, L., Vermaire, J., Rees, A.H., 2012. Midge-inferred temperature reconstructions and vegetation change over the last 15,000 years from Trout Lake northern Yukon Territory, eastern Beringia. Journal of Paleolimnology 48, 133-146.

Jones, B.M., Grosse, G., Arp, C.D., Jones, M.C., Walter Anthony, K.M., Romanovsky, V.E., 2011. Modern thermokarst dynamics in the continuous permafrost zone, northern Seward Peninsula, Alaska. Journal of Geophysical Research 116, G00M03. http:// dx.doi.org/10.1029/2011jg001666.

Kaufman, D.S., Manley, W.F., 2004. Pleistocene Maximum and Late Wisconsin glacier extents across Alaska, U.S.A. In: Ehlers, J., Gibbard, P.L. (Eds.), Quaternary Glaciations - Extent and Chronology, Part II, North America. : Developments in Quaternary Science, vol. 2b. Elsevier, Amsterdam, pp. 9-27.

Kaufman, D.S., Ager, T.A., Anderson, N.J., Anderson, P.M., Andrews, J.T., Bartlein, P.J. Brubaker, L.B., Coats, L.L., Cwynar, L.C., Duvall, M.L., Dyke, A.S., Edwards, M.E., Eisner, W.R., Gajewski, K., Geirsdottir, A., Hu, F.S., Jennings, A.E., Kaplan, M.R. Kerwin, M.W., Lozhkinm, A.V., MacDonald, G.M., Miller, G.H., Mock, C.J., Oswald, W.W., Otto-Bliesner, B.L., Porinchu, D.F., Rühland, K., Smol, J.P., Steig, E.J., Wolfe, 
B.B., 2004. Holocene thermal maximum in the western Arctic $\left(0-180^{\circ} \mathrm{W}\right)$. Quaternary Science Reviews 23, 529-560.

Keigwin, L.D., Donnelly, J.P., Cook, M.S., Driscoll, N.W., Brigham-Grette, J., 2006. Rapid sea-level rise and Holocene climate in the Chukchi Sea. Geology 34, 861-864.

Kennedy, K.E., Froese, D.G., Zazula, G.D., Lauriol, B., 2010. Last Glacial Maximum age for the northwest Laurentide maximum from the Eagle River spillway and delta complex, northern Yukon. Quaternary Science Reviews 29, 1288-1300.

Kokelj, S.V., Smith, C.A.S., Burn, C.R., 2002. Physical and chemical characteristics of the active layer and permafrost, Herschel Island, western Arctic Coast, Canada. Permafrost and Periglacial Processes 13, 171-185.

Kokelj, S.V., Jenkins, R.E., Milburn, D., Burn, C.R., Snow, N., 2005. The influence of thermokarst disturbance on the water quality of small upland lakes, Mackenzie Delta region, Northwest Territories, Canada. Permafrost and Periglacial Processes 16, 343-353.

Kurek, J., Cwynar, L.C., Vermaire, J.C., 2009. A late Quaternary paleotemperature record from Hanging Lake, northern Yukon Territory, eastern Beringia. Quaternary Research 72, 246-257.

Lantuit, H., Pollard, W.H., 2008. Fifty years of coastal erosion and retrogressive thaw slump activity on Herschel Island, southern Beaufort Sea, Yukon Territory, Canada. Geomorphology 95, 84-102.

Lantuit, H., Pollard, W.H., Couture, N., Fritz, M., Schirrmeister, L., Meyer, H., Hubberten, H.W., 2012. Modern and late Holocene retrogressive thaw slump activity on the Yukon Coastal Plain and Herschel Island, Yukon Territory, Canada. Permafrost and Periglacial Processes 23, 39-51.

Mackay, J.R., 1959. Glacier ice-thrust features of the Yukon Coast. Geographical Bulletin $13,5-21$.

Mackay, J.R., 1978. Freshwater shelled invertebrate indicators of paleoclimate in northwestern Canada during late glacial times: discussion. Canadian Journal of Earth Sciences $15,461-462$.

Mackay, J.R., 1990. Some observations on the growth and deformation of epigenetic, syngenetic and anti-syngenetic ice wedges. Permafrost and Periglacial Processes $1,15-29$.

Mackay, J.R., Dallimore, S.R., 1992. Massive ice of the Tuktoyaktuk area, western Arctic coast, Canada. Canadian Journal of Earth Sciences 29, 1235-1249.

Meyers, P.A., 1994. Preservation of elemental and isotopic source identification of sedimentary organic matter. Chemical Geology 144, 289-302.

Meyers, P.A., Lallier-Verges, E., 1999. Lacustrine sedimentary organic matter records of Late Quaternary paleoclimates. Journal of Paleolimnology 21, 345-372.

Moorman, B.J., Michel, F.A., Wilson, A.T., 1996. 14C dating of trapped gases in massive ground ice, western Canadian Arctic. Permafrost and Periglacial Processes 7 , 257-266.

Murton, J.B., 1996. Thermokarst-lake-basin sediments, Tuktoyaktuk Coastlands, western arctic Canada. Sedimentology 43, 737-760.

Murton, J.B., 2001. Thermokarst sediments and sedimentary structures, Tuktoyaktuk Coastlands, western Arctic Canada. Global and Planetary Change 28, 175-192.

Murton, J.B., French, H.M., Lamothe, M., 1997. Late Wisconsinan erosion and eolian deposition, Summer Island area, Pleistocene Mackenzie Delta, Northwest Territories: optical dating and implications for glacial chronology. Canadian Journal of Earth Sciences 34, 190-199.

Murton, J.B., French, H.M., Lamothe, M., 1998. The dating of thermokarst terrain, Pleistocene Mackenzie Delta, Canada. In: Lewkowicz, A.G., Allard, M. (Eds.), Seventh International Permafrost Conference. Nordicana, Yellowknife, NWT, Canada, 23-27 June, 1998, pp. 777-782.

Murton, J.B., Frechen, M., Maddy, D., 2007. Luminescence dating of mid- to Late Wisconsinan aeolian sand as a constraint on the last advance of the Laurentide Ice Sheet across the Tuktoyaktuk Coastlands, western Arctic Canada. Canadian Journal of Earth Sciences 44, 857-869.

Pienitz, R., Walker, I.R., Zeeb, B.A., Smol, J.P., Leavitt, P.R., 1992. Biomonitoring past salinity changes in an athalassic subarctic lake. International Journal of Salt Lake Research 1 (2), 91-123.

Pienitz, R., Smol, J.P., Last, W.M., Leavitt, P.R., Cumming, B.F., 2000. Multi-proxy Holocene palaeoclimatic record from a saline lake in the Canadian Subarctic. The Holocene 10 (6), 673-686.

Pollard, W.H., 1990. The nature and origin of ground ice in the Herschel Island area Yukon Territory. 5th Canadian Permafrost Conference. Québec: Nordicana, 54, pp. 23-30.

Rampton, V.N., 1974. The influence of ground ice and thermokarst upon the geomorphology of the Mackenzie-Beaufort region. In: Fahey, B.D., Thompson, R.D. (Eds.)
Research in Polar and Alpine Geomorphology. : Proceedings of the Third Guelph Symposium on Geomorphology. Geo-Abstracts, Norwich, pp. 43-59.

Rampton, V.N., 1982. Quaternary geology of the Yukon Coastal Plain. Geological Survey of Canada. Bulletin 317 (49 pp.).

Rampton, V.N., 1988. Quaternary geology of the Tuktoyaktuk Coastlands, Northwest Territories. Memoirs. Geological Survey of Canada 423.

Reimer, P.J., Baillie, M.G., Bard, E., Bayliss, A., Beck, J.W., Blackwell, P.G., Bronk Ramsey, C. Buck, C.E Burr, G.S, Edwards, R.L, Friedrich, M Grootes, P.M Guilderson, T.P. Hajdas, I., Heaton, T.J., Hogg, A.G., Hughen, K.A., Kaiser, K.F., Kromer, B., McCormac, F.G., Manning, S.W., Reimer, R.W., Richards, D.A., Southon, J.R., Talamo, S., Turney, C.S.M., van der Plicht, J., Weyhenmeyer, C.E., 2009. INTCAL09 and Marine09 radiocarbon age calibration curves, $0-50,000$ years cal BP. Radiocarbon 51, 1111-1150.

Ritchie, J.C., 1984. Past and Present Vegetation of the Far Northwest Canada. University of Toronto Press, Toronto (251 pp.)

Ritchie, J.C., Hare, F.K., 1971. Late-Quaternary vegetation and climate near the arctic tree line of northwestern North America. Quaternary Research 1, 331-342.

Ritchie, J.C., Cwynar, L.C., Spear, R.W., 1983. Evidence from north-west Canada for an early Holocene Milankovitch thermal maximum. Nature 305, 126-128.

Romanovskii, N.N., Hubberten, H.-W., Gavrilov, A.V., Tumskoy, V.E., Tipenko, G.S., Grigoriev, M.N., Siegert, C., 2000. Thermokarst and land-ocean interactions, Laptev Sea Region, Russia. Permafrost and Periglacial Processes 11, 137-152.

Rühland, K., St. Jacques, J.-M., Beierle, B.D., Lamoureux, S.F. Dyke, A.S., Smol, J.S., 2009. Lateglacial and Holocene paleoenvironmental changes recorded in lake sediments, Brock Plateau (Melville Hills), Northwest Territories, Canada. The Holocene 19 (7), 1005-1016.

Schweger, C.E., 1997. Late Quaternary palaeoecology of the Yukon: a review. In: Danks, H.V., Downes, J.A. (Eds.), Insects of the Yukon. Biological Survey of Canada, Ottawa, pp. $59-72$.

Scott, D.B., Schell, T., St-Onge, G., Rochon, A., Blasco, S., 2009. Foraminiferal assemblage changes over the last 15,000 years on the Mackenzie-Beaufort Sea Slope and Amundsen Gulf, Canada: implications for past sea ice conditions. Paleoceanography 24, PA2219. http://dx.doi.org/10.1029/2007PA001575.

Shephard, F.P., 1954. Nomenclature based on sand-silt-clay ratios. Journal of Sedimentary Petrology 24 (3), 151-158.

Smith, C.A.S., Kennedy, C.E., Hargrave, A.E., McKenna, K.M., 1989. Soil and Vegetation of Herschel Island, Yukon Territory, Yukon Soil Survey. Land Resource Research Centre, Agriculture Canada, Ottawa.

Smith, L.C., Sheng, Y., MacDonald, G.M., Hinzman, L.D., 2005. Disappearing Arctic lakes. Science 308, 1429.

Spear, R.W., 1993. The palynological record of Late-Quaternary arctic tree-line in northwest Canada. Review of Plaeobotany and Palynology 79, 99-111.

Szeicz, J.M., MacDonald, G.M., 2001. Montane climate and vegetation dynamics in easternmost Beringia during the Late Quaternary. Quaternary Science Reviews 20, 247-257.

Tomirdiaro, S.V., 1982. Evolution of lowland landscapes in northeastern Asia during late Quaternary time. In: Hopkins, D.M., Matthews Jr., J.V., Schweger, C.E., Young, S.B. (Eds.), Paleoecology of Beringia. Academic Press, New York, pp. 29-37.

Van Everdingen, R.O. (Ed.), 1998 revised May 2005. Multi-language Glossary of Permafrost and Related Ground-ice Terms. National Snow and Ice Data Center/World Data Center for Glaciology, Boulder, CO.

Vardy, S.R., Warner, B.G., Aravena, R., 1997. Holocene climate effects on the development of a peatland on the Tuktoyaktuk Peninsula, Northwest Territories. Quaternary Research 47, 90-104.

Viau, A.E., Gajewski, K., Sawada, M.C., Bunbury, J., 2008. Low- and high-frequency climate variability in eastern Beringia during the past 25000 years. Canadian Journal of Earth Sciences 45, 1435-1453.

Wetterich, S., Schirrmeister, L., Andreev, A.A., Pudenz, M., Plessen, B., Meyer, H., Kunitsky, V.V., 2009. Eemian and Late Glacial/Holocene palaeoenvironmental records from permafrost sequences at the Dmitry Laptev Strait (NE Siberia, Russia). Palaeogeography, Palaeoclimatology, Palaeoecology 279, 73-95.

Williams, J.R., Yeend, W.E., 1979. Deep thaw lake basins of the inner Arctic Coastal Plain. In: Johnson, K.M., Williams, J.R. (Eds.), The United States Geological Survey in Alaska -Accomplishments during 1978: U.S. Geological Survey Circular, 804-B, pp. B35-B37.

Zazula, G.D., Hare, P.G., Storer, J.E., 2009. New radiocarbon-dated vertebrate fossils from Herschel Island: implications for the palaeoenvironments and glacial chronology of the Beaufort Sea coastlands. Arctic 62, 273-280. 